\title{
Penerjemahan Makian dalam Webtoon Yakhan Yeongung ke dalam Bahasa Indonesia
}

\section{The Translation of Profanity in the Webtoon Yakhan Yeongung into Indonesian}

\author{
Ratu Syarifa Nurazizah ${ }^{1}$; Usmi ${ }^{2 *}$ \\ Universitas Indonesia ${ }^{1,2}$ \\ ratusn005@gmail.com¹,usmi07@ui.ac.id²
}

\begin{abstract}
Profanity is an expression used by someone for the purpose of berating, slandering, or expressing their anger towards others. In Korean, profanity also has another purpose, which is to show intimacy between the speakers and their partner. The purpose of this research is to explain how Korean profanity is translated into Indonesian in the webtoon Yakhan Yeongung. This research uses a descriptive analysis method with a qualitative approach and archival study as the research technique. This research includes Chang's profanity classification theory as well as Vinay and Dalbernet's translation theory as references. This research concludes that from the 28 profanity words identified in the data, 15 of them are simple profanities while the rest are compound profanities. Among those, there are two simple profanities and a compound profanity that were not translated. The translation methods used to translate these two kinds of profanity are also different. The simple profanity is translated using literal translation, transposition, equivalence and adaptation methods. Meanwhile, the compound profanity is translated using transposition, equivalence, adaptation, deletion and addition methods.
\end{abstract}

Keywords: profanity, translation method, webtoon corpus, Yakhan Yeongung

\section{INTISARI}

Makian merupakan ungkapan yang dituturkan oleh seseorang untuk tujuan mencaci-maki, menghujat, atau mengekspresikan kemarahannya pada orang lain. Dalam bahasa Korea, makian juga memiliki fungsi lain, yaitu untuk menunjukkan keakraban antara penutur dengan mitra tuturnya. Penelitian ini bertujuan untuk menjelaskan makian dalam bahasa Korea dan memaparkan teknik penerjemahan makian yang digunakan dalam webtoon Korea berjudul Yakhan Yeongung ke dalam bahasa Indonesia. Rumusan masalah dari penelitian ini adalah bagaimana makian berbahasa Korea dalam webtoon Yakhan Yeongung diterjemahkan ke dalam bahasa Indonesia. Penelitian ini menggunakan metode analisis deskriptif dengan pendekatan kualitatif dan studi pustaka. Sebagai acuan analisis, penelitian ini juga menggunakan teori klasifikasi makian yang dikemukakan oleh Chang dan teori penerjemahan Vinay dan Dalbernet. Hasil penelitian menunjukkan terdapat 28 makian yang muncul dalam data korpus yang diteliti, yakni 15 gibon yokseol dan 13 ganghwa yokseol. Di antara makian-makian tersebut, terdapat 2 gibon yokseol dan 1 ganghwa yokseol yang tidak diterjemahkan. Teknik yang digunakan untuk menerjemahkan kedua jenis makian tersebut berbeda. Gibon yokseol diterjemahkan dengan terjemahan harfiah, transposisi, ekuivalensi dan adaptasi. Sementara ganghwa yokseol diterjemahkan dengan transposisi, ekuivalensi, adaptasi, penghapusan dan penambahan.

Kata kunci: makian, teknik penerjemahan, korpus webtoon, Yakhan Yeongung

Saran sitasi:

Nurazizah, R.S., Usmi. (2021). Penerjemahan Makian dalam Webtoon Yakhan Yeongung ke dalam Bahasa Indonesia. JLA (Jurnal Lingua Applicata), 4(2), 99-121.

\footnotetext{
${ }^{1}$ First author

* Corresponding author
}

Copyright (C) 2021 The Author(s) This article is distributed under a 


\section{PENDAHULUAN}

Makian bukanlah hal yang asing di telinga masyarakat Korea. Dalam kehidupan sehari-hari, makian umumnya digunakan untuk mengekspresikan kemarahan atau kejengkelan penuturnya dalam suatu pembicaraan. Memaki adalah sebuah aktivitas linguistik yang melibatkan kata-kata tabu (Stapleton dalam Vingerhoets et al., 2013:288). Hal senada dikemukakan oleh Rosidin (2010:5), yang menegaskan bahwa makian atau kata-kata kotor digunakan untuk mencaci-maki, mengata-ngatai, menjelek-jelekkan, menghujat, dan sebagainya. Meskipun begitu, makian juga memiliki fungsi lain, yakni untuk menyatakan pujian, keheranan, atau menciptakan suasana keakraban dalam berkomunikasi selama ada kesepakatan di antara penutur dan mitra tutur. Tidak hanya itu, makian juga dapat digunakan untuk menunjukkan keakraban atau keintiman di antara penutur yang terlibat dalam satu percakapan (Rothwell dalam Rosidin, 2010:50). Dengan demikian, dapat disimpulkan bahwa dalam bahasa tertentu makian tidak hanya digunakan untuk menyatakan emosi seseorang, tetapi juga dapat digunakan untuk menunjukkan keakraban di antara para penutur dalam suatu percakapan.

Dalam hal ini, makian dapat ditemukan di berbagai bahasa yang muncul dalam berbagai bentuk dan cara. Tiap penutur dari pengguna bahasa yang berbeda tentunya memiliki cara yang berbeda dalam menyatakan makian. Dalam bahasa Korea, kata makian atau yokseol (욕설) biasanya disebut sangmal (상말), sangsori (상소리), yukdumunja (육두문자), atau yukdam (육담) yang bermakna kata-kata kasar yang bersifat rendah dan tidak terhormat. Dalam masyarakat feodal, makna ini ditujukan pada kata-kata yang digunakan rakyat biasa, bukan bangsawan. Kata makian dalam bahasa Korea hadir dalam empat bentuk, yakni kata, frasa, pewatas dan kalimat. Sementara itu, kata makian dalam bahasa Indonesia adalah kata-kata yang digunakan untuk menunjukkan ketidaksenangan, kebencian, atau ketidakpuasan terhadap situasi yang dihadapi seseorang. Kata-kata makian yang ada dalam bahasa Indonesia berbentuk kata monomorfemis, kata polimorfemis, frasa dan klausa. Hal ini menunjukkan bahwa makian dalam setiap bahasa memiliki keunikannya sendiri (Kim, 2002; Crystal, 2004; Wijana dan Rohmadi, 2012; Chang, 2010).

Seiring dengan berubahnya zaman, fungsi makian dalam masyarakat turut berubah. Pada zaman dahulu, makian jarang digunakan atau cenderung dihindari penggunaannya. Namun, saat ini penggunaan makian berubah menjadi hal yang lumrah dan pemakaiannya tidak terbatas pada gender atau usia. Meskipun begitu, untuk kalangan masyarakat tertentu penggunaan makian dikecam secara sosial, terutama makian yang menggunakan nama dewa-dewa (Montagu dalam Rahman, 2017; Ljung, 2011). Dengan adanya perubahan anggapan masyarakat terhadap ungkapan makian, lama kelamaan makian tidak hanya digunakan di publik tetapi juga dapat dilihat dalam bentuk tulisan. Hal ini dapat dilihat dalam beberapa karya sastra seperti novel, puisi, atau komik masa kini yang mengandung kata-kata makian di dalamnya. Berkat adanya perkembangan teknologi, di masa ini masyarakat tidak hanya menikmati karya sastra melalui bentuk cetak saja tetapi juga melalui internet.

Dewasa ini, frekuensi penggunaan internet oleh masyarakat meningkat pesat 
sehingga komik pun mulai memasuki ranah digital (Putri, 2018:2). Salah satu perwujudan dari komik digital yang didistribusikan melalui internet adalah webtoon. Webtoon berjudul Yakhan Yeongung yang dalam bahasa Indonesia berarti 'Pahlawan Lemah' merupakan webtoon karya SeoPass dan Kim Jin-seok yang dirilis oleh Naver Webtoon sejak tahun 2018. Webtoon ini juga telah dialihbahasakan ke dalam bahasa Indonesia dan diunggah di LINE Webtoon sejak tahun 2019. Webtoon Yakhan Yeongung bergenre aksi ini berlatar belakang kehidupan sekolah. Berdasarkan penelitian yang dilakukan oleh Yi et al. (2017), lebih dari dua pertiga dari kalangan remaja di Korea Selatan menggunakan makian secara tidak sadar dan berkala. Hampir semua kata yang dituturkan dalam suatu percakapan di kalangan remaja mengandung makian (Yi et al., 2017: 403-404). Karena webtoon ini berlatar cerita kehidupan di sekolah yang berisi remaja, dalam setiap percakapan para tokohnya banyak menggunakan makian. Oleh karena itu, penulis memilih webtoon Yakhan Yeongung sebagai korpus dari penelitian ini. Hingga kini, webtoon ini berjumlah 99 episode. Sebagai batasan penelitian, penulis hanya akan menggunakan 10 episode, yakni episode 76 hingga episode 85. Alasannya, karena pada episode 1 hingga episode 40 makian yang muncul dalam webtoon ini telah disensor sehingga sulit untuk mengetahui makian apa yang digunakan. Sebaliknya, variasi makian yang muncul dalam rentang episode 76-85 lebih beragam dibandingkan episode sebelumnya. Oleh karena itu, penelitian ini menggunakan episode 76 hingga episode 85 sebagai batas penelitian.
Berdasarkan paparan di atas, penelitian ini bertujuan untuk mengklasifikasikan dan menjelaskan penerjemahan makian dalam bahasa Korea. Korpus data yang digunakan adalah webtoon Korea berjudul Yakhan Yeongung. Penelitian ini dirancang untuk menjawab dua pertanyaan penelitian. Pertama, bagaimana pengklasifikasian makian yang terdapat dalam webtoon Yakhan Yeongung episode 76 hingga episode 85 menurut teori yang dikemukakan oleh Chang (2010). Kedua, bagaimana penerjemahan makian bahasa Korea ke dalam bahasa Indonesia.

\section{PENELITIAN TERDAHULU}

Bagian ini membahas tentang kajian atau penelitian terdahulu yang memiliki keterkaitan dengan penelitian ini. Tujuan pemaparan penelitian terdahulu ini untuk menentukan posisi penelitian ini dan menjelaskan perbedaannya. Fokus pembahasan terbagi menjadi dua, yakni penelitian yang membahas makian dalam bahasa Korea dan penelitian mengenai penerjemahan bahasa Korea ke bahasa Indonesia atau sebaliknya.

Penelitian mengenai makian telah dilakukan oleh Son et al. (2012), Baek (2013), dan Yang (2019). Son et al. (2012) meneliti tentang penyebab penggunaan makian di kalangan remaja. Mereka menggunakan pendekatan grounded theory (GT) dan menganalisis secara induktif dalam penelitiannya. Hasil penelitian menunjukkan penggunaan makian di kalangan remaja disebabkan oleh lingkungan budaya remaja, perubahan hubungan antar teman sebaya, serta perbedaan budaya antara remaja dan generasi sebelumnya. Di sisi 
lain, Baek (2013) menganalisis tren dan faktor psikologis dari penggunaan bahasa kasar di kalangan mahasiswa. Ia melakukan survei terhadap 224 mahasiswa dan menganalisis penggunaan bahasa kasar, alasan penggunaannya, serta sikap untuk menerima penggunaan bahasa tersebut. Hasil penelitian menunjukkan bahwa sebagian besar mahasiswa menggunakan bahasa kasar dan disebabkan oleh kemarahan. Terakhir, Yang (2019) mengkaji mengenai proses pembentukan budaya bahasa di kalangan remaja Korea dan berfokus pada penggunaan makian, bahasa kasar, bahasa gaul (slang) dan istilah populer (buzzwords). Ia menggunakan teknik coding untuk menganalisis data penelitian ini. Temuan penelitian ini adalah budaya bahasa di kalangan remaja Korea terbentuk karena adanya pengaruh teman dan internet. Bahasa-bahasa tersebut digunakan untuk berkomunikasi dengan teman sebayanya dan merasakan intimasi, solidaritas, serta rasa memiliki (sense of belonging).

Lebih lanjut, penelitian terdahulu yang membahas tentang penerjemahan bahasa Korea ke bahasa Indonesia atau sebaliknya telah dilakukan oleh Ni Made (2012), Nirwana dan Usmi (2019). Ni Made (2012) membahas tentang penerjemahan idiom bahasa Indonesia dalam novel Laskar Pelangi ke dalam bahasa Korea. Penelitiannya menggunakan teori pergeseran makna milik Catford (1965). Hasil penelitiannya menunjukkan terdapat hasil penerjemahan idiom dengan makna yang sepadan, hasil penerjemahan dengan makna yang tidak sepadan, serta idiom yang tidak diterjemahkan dalam bahasa Korea. Berbeda dengan penelitian tersebut, Nirwana dan Usmi (2019) membahas tentang penerjemahan kata bermuatan budaya dalam novel Laskar Pelangi dan Bellitung Seomui menggunakan teori penerjemahan dan teori istilah budaya yang dicetuskan Newmark (1988). Hasil penelitian menunjukkan bahwa kata yang paling banyak ditemukan adalah kata berkategori istilah budaya ekologi sebanyak 54 kata (53\%), terbanyak kedua adalah kata berkategori material budaya, sebanyak 37 kata (36\%) dari total 102 data temuan. Kemudian, 52 kata diterjemahkan dengan cara penyesuaian makna dari bahasa sumber ke bahasa target dan 50 kata tidak diterjemahkan.

Berbeda dengan penelitian-penelitian sebelumnya, penelitian ini berfokus pada penerjemahan makian bahasa Korea ke dalam bahasa Indonesia dan menggunakan webtoon sebagai data korpus. Dalam penelitian ini, penulis akan menggunakan teori Chang (2010) untuk mengklasifikasikan makian yang ada dalam korpus dan teori penerjemahan milik Vinay dan Dalbernet (1995) untuk mengidentifikasi teknik penerjemahan yang digunakan dalam menerjemahkan makian yang ada dalam webtoon Yakhan Yeongung.

\section{METODE PENELITIAN}

Penelitian ini menggunakan metode analisis deskriptif dengan pendekatan kuantitatif dan kualitatif. Metode penelitian ini merupakan metode yang dilakukan pada kondisi yang alamiah dengan menganalisis data berbentuk kata-kata atau gambar secara induktif dan lebih menekankan pada makna dan proses (Sugiyono, 2013). Dalam hal ini, penulis menggunakan dua sumber data. Data primer berupa webtoon Yakhan Yeongung bahasa Korea dan terjemahannya dalam bahasa Indonesia, 
sementara data sekunder berupa kajian pustaka, yakni sumber-sumber tidak langsung yang terkait dengan kata makian dan penerjemahan sebagai referensi.

Prosedur penelitian ini terdiri atas lima langkah. Pertama, meninjau data korpus sebagai sumber data primer. Kedua, mengidentifikasi data yang menjadi obyek penelitian, yakni kata makian. Ketiga, mengklasifikasikan kata makian berdasarkan teori Chang (2010). Keempat, menganalisis teknik penerjemahan berdasarkan teori Vinay dan Dalbernet (1995). Terakhir, pembahasan hasil penelitian dan menyimpulkan. Berikut ini adalah gambaran prosedur penelitian.

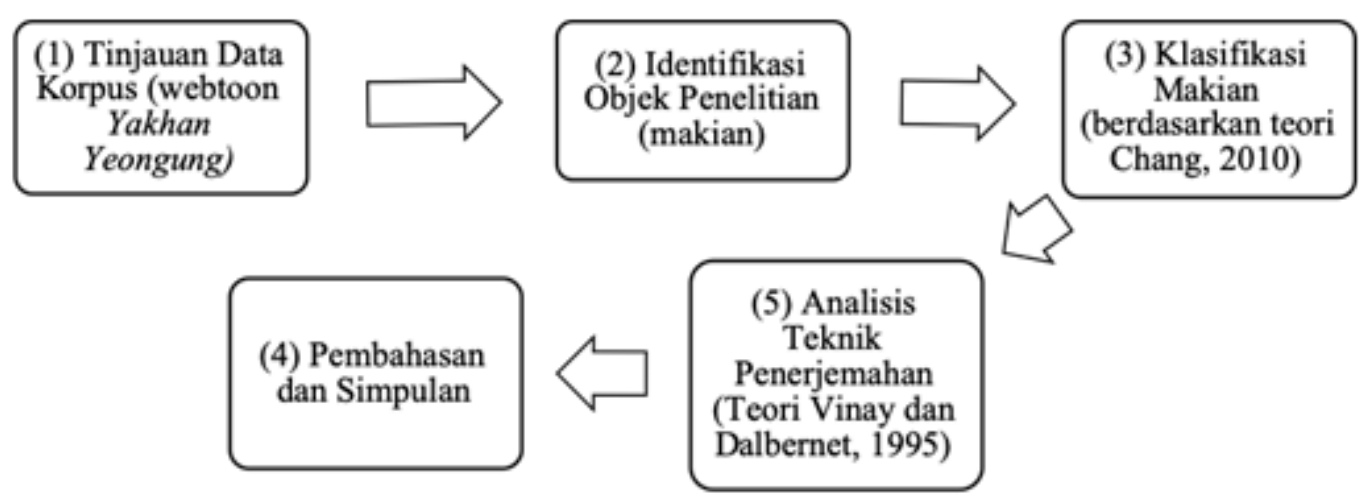

\section{Gambar 1. Prosedur Penelitian}

\section{LANDASAN TEORI}

\section{Definisi Makian}

Makian telah didefinisikan oleh beberapa ahli seperti Hughes (1991), Ljung (2011), Wijana dan Rohmadi (2012). Hughes mendefinisikan makian sebagai kata-kata bersifat cabul atau kasar dan dianggap tidak senonoh dalam suatu masyarakat yang digunakan untuk memaki seseorang. Kata-kata ini digunakan untuk mengejek, mengutuk, melukai, atau memperolok sesuatu ketika penutur memiliki emosi yang kuat (dalam Rosidin, 2010: 27). Sementara itu, Ljung (2011: 4) mendefinisikan makian sebagai bahasa emotif yang mengandung kata-kata tabu dan digunakan untuk merefleksikan, atau terlihat seperti merefleksikan, perasaan dan sikap penutur tanpa mengindahkan makna harfiahnya. Terakhir, Wijana dan Rohmadi (2012: 109) mendefinisikan makian sebagai kata-kata yang sering digunakan seseorang untuk mengekspresikan rasa kebencian, kemarahan, ketidaksenangan, atau ketidakpuasan terhadap situasi yang dihadapi penutur. Tidak jarang pula katakata ini digunakan untuk mengungkapkan pujian dan keheranan atau menciptakan suasana pembicaraan yang akrab. Dengan demikian dapat disimpulkan, makian merupakan ungkapan atau kata-kata bersifat tabu yang digunakan oleh penutur untuk mengungkapkan kemarahan, kekaguman, atau keakraban dalam berkomunikasi. 
Jenis Makian dalam Bahasa Korea dan Bahasa Indonesia

Setiap bahasa memiliki ragam makian tersendiri. Ungkapan atau kata yang dianggap sebagai makian dalam satu negara belum tentu dianggap sebagai makian di negara lain. Hal ini juga berlaku pada makian yang digunakan dalam bahasa Korea dan bahasa Indonesia. Pada bagian ini akan dipaparkan klasifikasi makian dalam bahasa Korea dan Indonesia.

Menurut Chang (2010: 403-424), makian dalam bahasa Korea dapat berbentuk kata, frasa, pewatas dan klausa. Berikut adalah contoh dari makian dalam bahasa Korea berdasarkan bentuknya.

1) Kata tunggal (danireo, 단일어): nom (놈), nyeon (년), saeki (새끼), babo (바보), jiralhada (지랄하다), dsb.

2) Kata kompleks (bokhapeo,복합어): gaenom (개놈), gaesaeki (개새끼), ssangnyeon (쌍년), jabnob (잡놈), akdang (악당), gaejiralhada (개지랄하다), dsb.

3) Klausa pewatas (susik guseong,수식 구성): michin-nom (미친 놈), ssokelnom (썩을 놈), babogaten-nom (바보 같은 놈), jotdo anin saeki (좇도 아닌 새끼), babo nom-ei saeki (바보 놈의 새끼), dsb.

4) Klausa keterangan (jeopsok guseong, 접속 구성): babdo an chomokko jirariya (밥도 안 처먹고 지랄이야), haru jongil kapchodaego jirariya (하루 종일 깝쳐대고 지랄이야), dsb.

Secara garis besar, makian dalam bahasa Korea dapat dibedakan menjadi dua jenis, yakni gibon yokseol (기본 욕설) dan ganghwa yokseol (강화 욕설). Gibon yokseol merupakan bentuk dasar makian dalam bahasa Korea yang pada umumnya merujuk kepada seseorang (Chang, 2010:417). Gibon yokseol dikelompokkan menjadi makian berupa kata ganti orang (inching yokseol, 인칭 욕설) dan makian non-kata ganti orang (bi-inching yokseol, 비인칭 욕설). Makian berupa kata ganti orang terdiri atas makian yang merujuk pada suatu tanda khusus yang dimiliki seseorang. Makian ini dapat diklasifikasikan kembali menjadi empat jenis: 1) makian yang mengindikasikan status; 2) makian yang mengindikasikan kepribadian; 3) makian yang mengindikasikan kecenderungan perilaku, dan 4) makian yang mengindikasikan karakteristik tubuh. Sementara itu, jumlah makian non-kata ganti orang tidak terlalu banyak dibandingkan makian berupa kata ganti orang. Berdasarkan kontennya, makian ini dikategorikan kembali menjadi empat jenis, yaitu 1) makian terkait kegiatan, 2) makian terkait sifat, 3) makian terkait derajat, serta 4) makian terkait emosi atau perasaan.

Sementara, ganghwa yokseol merupakan makian yang memiliki keagresifan lebih tinggi dibandingkan gibon yokseol. Makian ini terbentuk dengan menggabungkan dua jenis makian atau lebih (Chang, 2010:422). Makian jenis ini terbagi menjadi dua jenis berdasarkan pembentukan kata/ungkapan makian, yakni makian berbentuk komposisi dua kata (hapseong ganghwa yokseol,합성 강화 욕설) dan makian berbentuk penambahan dua kata (buyeon ganghwa yokseol, 부연 강화 
욕설). Dengan demikian dapat disimpulkan bahwa makian dalam bahasa Korea sangat beragam bentuknya dan dapat diklasifikasikan berdasarkan bentuk bahasa dan referensinya. Untuk lebih jelas, jenis makian dalam bahasa Korea beserta contohnya dapat dilihat pada Tabel 1 di bawah ini.

Tabel 1. Jenis Makian dalam Bahasa Korea

\begin{tabular}{|c|c|c|c|}
\hline \multicolumn{3}{|c|}{ Jenis Makian dalam Bahasa Korea } & \multirow{2}{*}{$\begin{array}{l}\text { Contoh } \\
\text { i-nom (이)놈, i-nyeon (이)년, saeki (새끼), kangphae } \\
\text { (깡패), jolgae (졸개), chopja (첩자) dsb. }\end{array}$} \\
\hline $\begin{array}{l}\text { Gibon } \\
\text { yokseol }\end{array}$ & $\begin{array}{l}\text { Kata ganti } \\
\text { orang }\end{array}$ & Status & \\
\hline & & Kepribadian & $\begin{array}{l}\text { akma (악마), akdang (악당), meongchongi (멍청이), } \\
\text { byeongsin (병신) dsb. }\end{array}$ \\
\hline & & $\begin{array}{l}\text { Kecenderungan } \\
\text { perilaku }\end{array}$ & $\begin{array}{l}\text { gopchaengi (겁쟁이), phokgun (폭군), geolle (걸레), } \\
\text { pongjaengi (뻥쟁이) dsb. }\end{array}$ \\
\hline & & Karakteristik tubuh & $\begin{array}{l}\text { motsenggin nom (못생긴 놈), kopchu (꼽추), tungtungi } \\
\text { (똥똥이), neltari (늙다리) dsb. }\end{array}$ \\
\hline & $\begin{array}{l}\text { Non-kata } \\
\text { ganti orang }\end{array}$ & Kegiatan/tindakan & $\begin{array}{l}\text { keopjeogeorida (껍적거리다), jiralhada (지랄하다), } \\
\text { chomogta (처먹다) dsb. }\end{array}$ \\
\hline & & Sifat/keadaan & $\begin{array}{l}\text { meongcheonghada (멍청하다), michida (미치다), jotgatta } \\
\text { (좇같다) dsb. }\end{array}$ \\
\hline & & Derajat & jotnage (좇나게), jotna (좇나) dsb. \\
\hline & & Emosi/perasaan & jegiral (제기랄), sibal (씨발), urajil (우라질) dsb. \\
\hline \multirow[t]{2}{*}{$\begin{array}{l}\text { Ganghwa } \\
\text { yokseol }\end{array}$} & \multicolumn{2}{|c|}{ Makian komposisi dua kata } & $\begin{array}{l}\text { chonnom saeki(촌놈 새끼), babo saeki (바보 새끼), } \\
\text { sipsaeki (씹새끼), sipnyeon (십년), gaenom saeki (개놈 } \\
\text { 새끼), yeombyeongjira hada (염병지랄하다) dsb. }\end{array}$ \\
\hline & \multicolumn{2}{|c|}{ Makian penambahan dua kata } & $\begin{array}{l}\text { michin nom (미친 놈), ssibal nom (씨발 놈), jotna } \\
\text { cheomeogta (좇나 처먹다), bulyeo-u gaten nyeon (불여우 } \\
\text { 같은 년), cheonbeolbadel nom (천벌받을 놈) dsb. }\end{array}$ \\
\hline
\end{tabular}

(Disadur dari Chang, 2010: 417-424)

Berbeda dengan bahasa Korea, makian dalam bahasa Indonesia memiliki klasifikasi tersendiri. Wijana dan Rohmadi (2012:115-130) memaparkan bahwa kata makian dalam bahasa Indonesia dapat berbentuk kata monomorfemis, kata polimorfemis, frasa, dan klausa. Berikut adalah contoh makian dalam bahasa Indonesia berdasarkan bentuknya.

Tabel 2. Jenis Makian dalam Bahasa Indonesia

\begin{tabular}{ll}
\hline $\begin{array}{l}\text { Jenis Makian dalam } \\
\text { Bahasa Indonesia }\end{array}$ & Contoh \\
\hline Kata monomorfemis & Babi, bangsat, setan, dsb. \\
Kata polimorfemis & Sialan, bajingan, kampungan, diancuk, diamput, dsb. \\
Frasa & Dasar buaya, dasar pelacur, dasar gila, dsb. \\
Klausa & Gila kamu, sundal kamu, gila benar dia, dsb. \\
\hline
\end{tabular}

(Disadur dari Wijana dan Rohmadi, 2012:115-118) 
Apabila dilihat dari referensinya, kata-kata makian dalam bahasa Indonesia dapat diklasifikasikan berdasarkan keadaan, binatang, benda-benda, bagian tubuh, kekerabatan, makhluk halus, aktivitas, dan profesi. Tabel 3 menjelaskan pemakaian makian berdasarkan referensi beserta contohnya.

\section{Tabel 3. Makian dalam Bahasa Indonesia Berdasarkan Referensi}

\begin{tabular}{|c|c|c|}
\hline Referensi & Penjelasan & Contoh \\
\hline Keadaan & $\begin{array}{l}\text { Merujuk pada keadaan yang tidak menyenangkan } \\
\text { seperti keadaan mental, keadaan yang tidak direstui } \\
\text { Tuhan atau agama, serta keadaan yang tidak } \\
\text { menyenangkan yang menimpa seseorang. }\end{array}$ & $\begin{array}{l}\text { Gila, sinting, bodoh, } \\
\text { celaka, mati, mampus } \\
\text { keparat, jahanam, } \\
\text { terkutuk. }\end{array}$ \\
\hline Binatang & $\begin{array}{l}\text { Merujuk kepada binatang-binatang yang memiliki sifat } \\
\text { menjijikkan, diharamkan, mengganggu, menyakiti, dan } \\
\text { senang mencari pasangan. }\end{array}$ & $\begin{array}{l}\text { Anjing, babi, bangsat, } \\
\text { lintah darat, buaya. }\end{array}$ \\
\hline Benda-benda & $\begin{array}{l}\text { Merujuk pada benda-benda yang memiliki keburukan } \\
\text { seperti bau tidak sedap, kotor dan usang, dan suara } \\
\text { yang mengganggu. }\end{array}$ & Tai, gombal, sompret \\
\hline Bagian tubuh & $\begin{array}{l}\text { Merujuk pada anggota tubuh yang erat kaitannya } \\
\text { dengan aktivitas seksual. }\end{array}$ & Puki mak, cuki mai \\
\hline Kekerabatan & $\begin{array}{l}\text { Merujuk pada individu yang dihormati dan } \\
\text { ditambahkan klitika - } m u \text {. }\end{array}$ & Kakekmu, nenekmu \\
\hline Makhluk halus & $\begin{array}{l}\text { Merujuk pada makhluk halus yang sering mengganggu } \\
\text { manusia. }\end{array}$ & Setan, iblis \\
\hline Aktivitas & Merujuk pada aktivitas seksual. & Diamput, diancuk \\
\hline Profesi & $\begin{array}{l}\text { Merujuk pada profesi rendah dan diharamkan oleh } \\
\text { agama. }\end{array}$ & $\begin{array}{l}\text { Maling, bajingan, } \\
\text { copet, cecunguk }\end{array}$ \\
\hline
\end{tabular}
(Disadur dari Wijana dan Rohmadi, 2012:119-125)

Berdasarkan kajian literatur makian dalam bahasa Korea dan Indonesia, dapat disimpulkan bahwa terdapat beberapa perbedaan antara makian dalam bahasa Korea dan bahasa Indonesia. Pertama, makian dalam bahasa Korea dapat hadir dalam bentuk nomina, verba maupun adjektiva. Sementara, makian dalam bahasa Indonesia lebih banyak berbentuk nomina dan adjektiva. Kedua, penggunaan makian dalam bahasa Korea lebih banyak lebih banyak merujuk pada status, penampilan, perilaku atau kepribadian yang berkaitan langsung dengan mitra penutur, sedangkan makian dalam bahasa Indonesia diekspresikan secara metaforis dengan menggunakan sebuah referensi yang memiliki sifat-sifat sebanding dengan sifat individu atau keadaan yang menjadi sasaran makian. Ketiga, berbeda dengan bahasa Indonesia, makian yang menggunakan binatang dan kekerabatan sebagai referensi jarang ditemukan dalam makian berbahasa Korea (Chang, 2010; Rosidin, 2010; Wijana dan Rohmadi, 2012). 


\section{Teori Penerjemahan}

Beberapa ahli telah mendefinisikan penerjemahan. Catford (1965, dalam Dewi dan Wijaya, 2020:2) mendefinisikan penerjemahan sebagai penggantian materi tekstual pada teks sumber ke dalam materi tekstual pada teks sasaran. Sementara itu, Nida dan Taber (dalam Dewi dan Wijaya, 2020:2) mendefinisikan penerjemahan sebagai kegiatan untuk menghasilkan kembali suatu pesan bahasa sumber dengan padanan yang paling alamiah dalam bahasa sasaran. Pendapat senada dikemukakan oleh Hoed (2006:23) mendefinisikan penerjemahan sebagai kegiatan mengalihkan pesan secara tertulis dari teks sumber ke dalam teks sasaran. Dengan demikian dalam penelitian ini, penerjemahan secara sederhana dapat didefinisikan sebagai suatu kegiatan pengalihan pesan dari satu bahasa ke bahasa lainnya.

Dalam penerjemahan, terdapat beberapa unsur penting yang perlu diperhatikan, di antaranya adalah teks sumber dan teks sasaran. Teks sumber (TSu) merupakan teks yang harus diterjemahkan oleh seorang penerjemah dan bahasa yang digunakan disebut sebagai bahasa sumber (BSu). Sementara, teks sasaran (TSa) merupakan teks yang dihasilkan dari kegiatan terjemahan suatu TSu dan bahasa yang digunakan disebut sebagai bahasa sasaran (BSa). Selain itu, unsur penting lainnya yang perlu diperhatikan adalah makna dan pesan. Konsep makna dan pesan berbeda. Makna merujuk kepada arti semantis atau arti harfiah suatu kata, frasa, ungkapan, atau kalimat. Sebaliknya, pesan merujuk kepada arti pragmatis atau kontekstual, yakni gagasan utama yang ingin disampaikan melalui suatu ujaran atau tulisan (Newmark, 1988; Hoed, 2006; Dewi dan Wijaya, 2020). Singkat kata, empat unsur penting yang perlu diperhatikan dalam penerjemahan adalah teks sumber, teks sasaran, makna dan pesan yang ingin disampaikan lewat penerjemahan.

Dalam hal ini, Hoed (2006:39-40) menegaskan ada tiga prinsip yang mendasari proses penerjemahan. Pertama, penerjemahan selalu bersifat satu arah, yakni bertolak dari teks sumber (TSu) untuk menghasilkan teks sasaran (TSa). Kedua, penerjemah berada di antara dua bahasa dan dua kebudayaan yang melatari setiap bahasa yang terlibat di dalamnya. Yang terakhir, penerjemah mengungkapkan kembali pesan yang terkandung dalam $\mathrm{TSu}$ ke dalam bentuk TSa dengan pengetahuan dan kemahirannya. Oleh karena itu, penerjemahan suatu pesan bisa saja tidak sesuai dengan makna harfiahnya, tetapi masih memiliki 'rasa' yang ingin disampaikan oleh penyampai pesan. Tentu saja, hal ini juga berlaku dalam penerjemahan makian yang ada dalam komik webtoon yang merupakan bagian dari karya sastra lisan.

Untuk menghasilkan terjemahan yang sepadan dengan pesan yang ingin disampaikan oleh penyampai pesan, dibutuhkan cara penerjemahan yang tepat. Cara penerjemahan ini dikenal sebagai teknik penerjemahan. Berbagai ahli dalam studi penerjemahan telah mencetuskan 
beberapa teknik penerjemahan, di antaranya adalah Jean-Paul Vinay dan Jean Dalbernet. Vinay dan Dalbernet (1995, dalam Hatim dan Munday 2004:148-151) membagi teknik penerjemahan ke dalam tujuh kategori. Ketujuh kategori ini dibagi ke dalam dua kelompok besar teknik penerjemahan, yaitu penerjemahan langsung (direct translation) dan penerjemahan tidak langsung (oblique translation).

Penerjemahan langsung merupakan penerjemahan yang dilakukan apabila penerjemah dapat mengubah setiap elemen yang ada di pesan dalam BSu ke dalam bentuk BSa. Teknik penerjemahan yang termasuk ke dalam teknik penerjemahan langsung, antara lain: 1) peminjaman/borrowing, 2) calque, dan 3) terjemahan harfiah/literal translation. Sementara itu, penerjemahan tidak langsung merupakan penerjemahan yang dilakukan apabila terdapat celah dalam BSa yang harus diisi dengan padanan yang sesuai. Selain itu, teknik ini juga digunakan ketika ada gaya bahasa tertentu yang tidak dapat diubah ke dalam BSa tanpa mengubah susunan sintaksis atau leksis. Teknik penerjemahan yang termasuk dalam teknik ini, sebagai berikut: 1) transposisi/ transposition, 2) modulasi/modulation, 3) ekuivalensi/equivalence, serta 4) adaptasi/adaptation (Vinay dan Dalbernet dalam Hatim dan Munday, 2004:148-151). Selain ketujuh teknik tersebut, Vinay dan Dalbernet (1965, dalam
Dewi dan Wijaya 2020:87-94) juga mengusulkan empat teknik penerjemahan lainnya, yakni: 1) eksplisitasi/explicitation, 2) implisitasi/implicitation, 3) penghapusan/deletion, dan 4) penambahan/ addition.

\section{HASIL PENELITIAN DAN PEMBAHASAN}

Seperti yang telah dipaparkan di atas, bentuk makian dalam bahasa Korea terbagi menjadi dua jenis, yaitu gibon yokseol dan ganghwa yokseol. Dari korpus data sepuluh episode webtoon Yakhan Yengung, ditemukan dua puluh delapan (28) ungkapan makian. Lima belas (15) di antaranya merupakan gibon yokseol dan tiga belas (13) lainnya merupakan ganghwa yokseol. Selanjutnya, pembahasan hasil penelitian terbagi menjadi dua, yakni penerjemahan makian berjenis gibon yokseol dan berjenis ganghwa yokseol.

\section{Penerjemahan Makian Berjenis Gibon Yokseol}

Jenis gibon yokseol yang muncul dalam korpus adalah makian berupa kata ganti orang dan non-kata ganti orang. Gibon yokseol jenis kata ganti orang yang muncul berjumlah 6 buah, sementara gibon yokseol jenis non-kata ganti orang yang muncul berjumlah 9 buah. Tabel berikut menunjukkan gibon yokseol yang ditemukan dalam webtoon Yakhan Yeongung beserta terjemahannya. 
Tabel 4. Gibon Yokseol dalam webtoon Yakhan Yeongung dan Terjemahannya

\begin{tabular}{|c|c|c|c|}
\hline \multicolumn{2}{|c|}{ Tipe Gibon Yokseol } & \multirow{2}{*}{$\frac{\text { Makian }}{[\mathrm{i} / \mathrm{ge}] \text { nom (이/그)놈 }}$} & \multirow{2}{*}{$\begin{array}{l}\text { Terjemahan } \\
\text { anak, cecunguk, kata ganti orang } \\
\text { (mereka, dia), tidak diterjemahkan }\end{array}$} \\
\hline $\begin{array}{l}\text { Kata ganti } \\
\text { orang }\end{array}$ & Status & & \\
\hline \multirow{13}{*}{$\begin{array}{l}\text { Non-kata } \\
\text { ganti } \\
\text { orang }\end{array}$} & & [i/ge] nyeon (이/그)년 & cewek (itu) \\
\hline & & saeki (새끼) & $\begin{array}{l}\text { sialan, bajingan, keparat, brengsek, } \\
\text { bedebah, cecunguk, tengik, orang } \\
\text { (ini/itu), anak (ini/itu), kata ganti } \\
\text { orang (kalian, mereka, dia), tidak } \\
\text { diterjemahkan } \\
\text { anak (ini/itu) }\end{array}$ \\
\hline & & inma (인마) & tidak diterjemahkan \\
\hline & Kepribadian & byeongsin (병신) & bodoh, idiot \\
\hline & Kegiatan/Tindakan & jiral (지랄) & Ngelawak \\
\hline & & jiralhada (지랄하다) & banyak tingkah \\
\hline & Emosi/perasaan & ssibal (씨발) & $\begin{array}{l}\text { bangsat, geblek, sialan, sial, tidak } \\
\text { diterjemahkan }\end{array}$ \\
\hline & Derajat & jotka (좇까) & diam kau \\
\hline & & jotbap (좇밥) & Pecundang \\
\hline & & jotna (좇나/존나) & $\begin{array}{l}\text { sok-sok, banget/sekali, tidak } \\
\text { diterjemahkan }\end{array}$ \\
\hline & Sifat/Keadaan & nyeon-gatta (년같다) & tidak diterjemahkan \\
\hline & & jotdweda (좆되다) & Mampus \\
\hline & & jot-gatta (좇같다) & $\begin{array}{l}\text { jelek, ngeselin, bikin kesal, merasa } \\
\text { kesal }\end{array}$ \\
\hline
\end{tabular}

(Sumber data: data temuan penelitian)

Berdasarkan teknik penerjemahan yang dikemukakan oleh Vinay dan Dalbernet, yang telah dipaparkan di atas, teknik yang digunakan untuk menerjemahkan gibon yokseol dalam data korpus yang diteliti adalah teknik terjemahan harfiah, transposisi, ekuivalensi, dan adaptasi. Di antara teknik-teknik ini, teknik penerjemahan yang paling sering digunakan adalah teknik ekuivalensi. Sementara, teknik penerjemahan yang tidak digunakan adalah teknik peminjaman, calque, modulasi, eksplisitasi, implisitasi, penghapusan dan penambahan. Selain itu, terdapat pula beberapa gibon yokseol yang tidak diterjemahkan karena tidak ditemukan padanan yang sesuai.

Tabel 5 di bawah ini menunjukkan teknik penerjemahan yang digunakan untuk menerjemahkan gibon yokseol dalam data korpus beserta contohnya. Berikut ini adalah paparan Tabel 5. 
Tabel 5. Teknik Penerjemahan Gibon Yokseol

\begin{tabular}{lll}
\hline Teknik Penerjemahan & Bahasa Sumber & Bahasa Sasaran \\
\hline Terjemahan Harfiah (1 makian) & jasik (자식) & anak \\
Transposisi (1 makian) & jiral (지랄) & ngelawak \\
Ekuivalensi (6 makian) & nyeon (년) & cewek \\
& jiral-el hada (지랄을 하다) & banyak tingkah \\
& jot-gatta (좇같다) & ngeselin, bikin kesal, merasa kesal \\
& nom (놈) & anak, cecunguk, mereka/dia \\
& saeki (새끼) & sialan, bajingan, keparat, brengsek, \\
& & bedebah, cecunguk, tengik, kata ganti \\
& jiral (지랄) & orang \\
& ssibal (씨발) & bangsat, geblek, sialan, sial \\
Adaptasi (5 makian) & jotbap (좇밥) & pecundang \\
& jot-dweda (좆되다) & mampus \\
& jotka (좇까) & diam kau \\
& jotna (좇나) & sok-sok, banget/sekali
\end{tabular}

(Sumber data: data temuan penelitian)

Pertama, terjemahan harfiah (literal translation). Terjemahan harfiah adalah sebuah teknik penerjemahan secara harfiah dari TSu ke dalam TSa dengan mengikuti tata bahasa dan struktur kalimat yang tepat (Vinay dan Dalbernet dalam Hatim dan Munday, 2004:149). Teknik ini digunakan untuk menerjemahkan salah satu makian yang muncul dalam data korpus, yaitu makian 'jasik' (자식).

Berdasarkan Kamus Besar Bahasa Korea (selanjutnya disingkat KBBS) dari laman National Institute of Korean Language (국립국어원) Republic of Korea, kata makian jasik (자식) memiliki tiga makna. Makna pertama adalah '부모가 낳은 아이를, 그 부모에 상대하여 이르는 말' yang berarti kata yang digunakan orang tua untuk memanggil anaknya. Makna kedua adalah '어린아이를 귀엽게 이르는 말' yang berarti kata yang digunakan untuk memanggil anak kecil dengan afeksi. Terakhir, kata jasik didefinisikan sebagai '남자를 욕할 때 ‘놈’보다 낮추어 이르는 말' yang berarti kata yang lebih merendahkan dibanding makian nom (놈) untuk memaki seorang laki-laki.

Dari ketiga makna tersebut, makna ketiga lebih merujuk kepada makna kontekstual dan tidak menunjukkan makna harfiah dari kata jasik. Sementara itu, meskipun makna pertama dan kedua berbeda secara kontekstual, keduanya mengindikasikan bahwa jasik adalah panggilan untuk seorang anak. Berdasarkan penjelasan tersebut, dapat diketahui bahwa kata makian jasik diterjemahkan secara 
harfiah meskipun menghilangkan nuansa makian yang dimilikinya.

Kedua, transposisi (transposition). Transposisi merupakan teknik penerjemahan yang mengakibatkan pergeseran secara struktur dari BSu ke BSa. Perubahan yang terjadi bisa berupa perubahan susunan kata dalam frasa, klausa, atau kalimat (Vinay dan Dalbernet dalam Dewi dan Wijaya, 2020:45). Dalam penerjemahan bahasa Korea ke bahasa Indonesia sendiri sering menggunakan teknik ini, karena struktur yang dimiliki bahasa Korea dan bahasa Indonesia berbeda. Misalnya, struktur kalimat dalam bahasa Korea merupakan SOP (subjek-objekpredikat) sementara struktur kalimat dalam bahasa Indonesia merupakan SPO (subjekpredikat-objek) sehingga harus diterjemahkan dengan teknik transposisi. Dari data yang telah ditinjau, dapat diketahui bahwa teknik ini digunakan untuk menerjemahkan salah satu gibon yokseol yang muncul yakni jiral (지랄). Ungkapan kata makian jiral merupakan kata benda, namun terjemahannya adalah 'ngelawak' yang merupakan kata kerja. Hal ini menunjukkan bahwa teknik penerjemahan transposisi digunakan karena terjadinya perubahan kelas kata.

Ketiga, ekuivalensi (equivalence). Ekuivalensi merupakan teknik yang menerjemahkan suatu pesan dengan struktur dan gaya BSa yang benar-benar berbeda dengan BSu. Meskipun maknanya berbeda, pesan yang ingin disampaikan oleh $\mathrm{TSu}$ tetap tersampaikan (Vinay dan Dalbernet dalam Hatim dan Munday,
2004:150). Beberapa makian dalam webtoon Yakhan Yeongung yang diterjemahkan menggunakan teknik ini adalah makian nom, nyeon, saeki, jiral, jirar-el hada dan jot-gatta.

Pada kasus penerjemahan makian nyeon (년), padanan yang digunakan sebagai terjemahan adalah 'cewek.' Dalam KBBS, kata nyeon (년) memiliki makna '여자를 낮잡아 이르는 말' yakni kata kasar yang digunakan untuk memanggil seorang perempuan. Padanan ini sesuai dengan makna yang dimiliki oleh nyeon, namun kurang tepat karena padanan ini bukan merupakan kata makian dalam bahasa Indonesia.

Makian lain yang juga menunjukkan penggunaan teknik ekuivalensi ialah makian jirar-el hada (지랄을 하다). Berdasarkan KBBS, jirar-el hada memiliki makna '(속되게) 마구 법석을 떨며 분별없이 행동하다' yang berarti 'membuat keributan dan bersikap kurang ajar'. Dalam penerjemahan makian ini, penerjemah menggunakan padanan 'banyak tingkah' sebagai terjemahan. Padanan ini sesuai dengan makna yang dimiliki makian 'jirarel hada (지랄을 하다)' meskipun padanan 'banyak tingkah' bukan merupakan makian dalam bahasa Indonesia.

Di samping makian-makian di atas, terjemahan makian jot-gatta (좇같다) juga menunjukkan penggunaan teknik ekuivalensi. Makian jot-gatta merupakan gabungan dari kata jot dan gatta. Meskipun keduanya memiliki makna tersendiri, apabila kedua kata ini digabungkan maka terbentuk makna yang baru yang berbeda 
dari makna awalnya. Dalam KBBS, makian jot-gatta didefinisikan sebagai '(비속하게) 사물이 몹시 마음에 안 들거나 보기에 싫다' yang berarti bahasa kasar untuk menyatakan tidak menyukai sesuatu. Makna ini sesuai dengan padanan yang digunakan untuk menerjemahkan jot-gatta, yakni 'ngeselin', 'bikin kesal' dan 'merasa kesal' yang menunjukkan sikap tidak menyukai sesuatu. Meskipun memiliki makna yang sesuai, padanan ini bukan merupakan makian dalam bahasa Indonesia sehingga menunjukkan penggunaan teknik ekuivalensi.

Keempat, adaptasi (adaptation). Adaptasi merupakan teknik yang digunakan apabila terdapat suatu situasi dalam BSu yang tidak dikenal dalam BSa. Dalam kasus ini, penerjemah menciptakan suatu situasi baru yang sepadan dengan situasi BSu tersebut (Vinay dan Dalbernet dalam Hatim dan Munday, 2004:151). Berdasarkan data yang telah ditinjau, beberapa makian yang diterjemahkan dengan teknik ini adalah ungkapan ssibal (씨발), jot- $d w e d a$ (좇되다), jotka (좇까), jotbap (좇밥) dan jotna (좇나).

Makian ssibal (씨발) yang muncul dalam data korpus diterjemahkan sebagai 'bangsat', 'geblek', 'sialan', dan 'sial.' Ungkapan ssibal merupakan kombinasi dari kata '씹' dan kata '할' dari '하다.' Berdasarkan KBBS, ungkapan ssib (씹) didefinisikan sebagai 1) 여성의 성교를 비속하게 이르는 말 atau kata-kata kasar yang merujuk pada organ seksual perempuan; 2) '성교'를 비속하게 이르는 말 atau kata-kata kasar yang merujuk pada kata 'seks.' Meskipun dalam bahasa Indonesia terdapat makian yang menggunakan organ seksual sebagai referensi, tetapi ungkapan tersebut jarang digunakan dan situasi pemakaiannya juga kurang sesuai. Oleh karena itu, penerjemah menggunakan padanan 'bangsat', 'geblek', 'sialan' dan 'sial' yang lebih lazim digunakan sebagai makian dalam bahasa Indonesia.

Sementara itu, makian jot-dweda, jotka, jotbap, dan jotna (좇나) juga diterjemahkan dengan teknik adaptasi. Berbeda dengan ungkapan makna jot-gatta yang mengalami perubahan makna setelah kata jot digabungkan dengan gatta, makna keempat makian ini tidak berubah setelah dikombinasikan. Dalam KBBS, kata jot memiliki makna '남성의 성기를 비속하게 이르는 말' yang berarti kata kasar yang merujuk pada alat kelamin laki-laki. Namun, karena kata jot digabungkan dengan kata lain, tidak ada padanan yang cukup sesuai dengan ungkapan-ungkapan tersebut. Oleh karena itu, penerjemah mencari padanan lain yang sesuai dengan pesan yang ingin disampaikan dalam webtoon Yakhan Yeongung. Perhatikan contoh berikut.

(1) 성일중 동창회 하는 거야? 여전히 좃밥 사이에서 꼰대 놀이하는 거 보니... 이 선생 너는 중학교 때 나한테 덜 맞을 것 같다.

[seong-iljung dongchanghoe haneun geoya? yeojeonhi jotbap saieseo kkondae nol-ihaneun geo boni... $i$ seonsaeng neoneun junghaggyo ttae nahante deol majeul geos gatda] 
"Ini lagi alumni SMP Sungil? Kalau melihat kalian masih suka sok berguru di antara pecundang... Sepertinya kau belum cukup kupukul waktu SMP."

Tuturan pada contoh (1) tersebut merupakan dialog yang terjadi ketika penutur melihat tiga orang yang dulu berasal dari SMP yang sama dengannya sedang menindas seseorang. Namun, penutur mengetahui bahwa ketiga orang tersebut hanya menindas orang-orang yang lebih lemah dari mereka. Untuk menerjemahkan jotbap yang merujuk pada orang-orang yang ditindas tersebut, penerjemah memilih padanan 'pecundang' yang memiliki makna 'yang kalah' atau 'yang dikalahkan.' Makna yang dimiliki padanan ini sesuai untuk merujuk orangorang yang ditindas tersebut sembari tetap mempertahankan nuansa makian yang dimiliki ungkapan jotbap.

Selain teknik penerjemahan di atas, terdapat pula makian-makian yang tidak diterjemahkan karena tidak ada padanan yang tepat baik secara harfiah maupun kontekstual. Makian yang tidak diterjemahkan sama sekali dan tidak ditemukan padanannya adalah nyeon-gatta dan inma. Selain itu, terdapat pula makian yang ditemukan padanannya, namun dalam beberapa konteks tidak dapat diterjemahkan seperti nom, saeki, ssibal dan jotna/jonna.
Pada kasus-kasus seperti ini, makna dari makian tersebut menghilang dan tidak diganti dengan padanan apa pun sebagai terjemahannya.

\section{Penerjemahan Makian Berjenis Ganghwa Yokseol}

Berdasarkan temuan data, makian berjenis ganghwa yokseol sebanyak 13 makian. Seperti yang telah dijelaskan, ganghwa yokseol dapat berupa gabungan dari dua makian atau gabungan dari makian dan bahasa kasar. Namun, bentuk dari beberapa terjemahan ganghwa yokseol yang ada dalam webtoon Yakhan Yeongung cukup berbeda dengan bentuk awalnya. Tabel 6 menunjukkan ganghwa yokseol yang ada dalam webtoon tersebut beserta terjemahannya.

Berdasarkan data pada tabel 6, teknik penerjemahan yang digunakan untuk menerjemahkan ganghwa yokseol dalam data korpus agak berbeda dengan penerjemahan gibon yokseol. Teknik penerjemahan yang digunakan adalah teknik transposisi, ekuivalensi, adaptasi, penghapusan dan penambahan. Di antara teknik-teknik tersebut, teknik yang lazim digunakan untuk menerjemahkan ganghwa yokseol adalah teknik penghapusan. Di sisi lain, teknik penerjemahan yang tidak digunakan adalah teknik peminjaman, calque, terjemahan harfiah, modulasi, eksplisitasi dan implisitasi. 
Tabel 6. Ganghwa Yokseol dalam webtoon Yakhan Yeongung dan Terjemahannya

\begin{tabular}{lll}
\hline Tipe Ganghwa Yokseol & Bahasa Sumber & Bahasa Sasaran \\
\hline Makian komposisi dua kata & gaesaeki (개새끼) & $\begin{array}{l}\text { bajingan sialan, cecunguk, keparat, } \\
\text { sialan, bedebah, bangsat } \\
\text { anak tolol, bangsat, keparat }\end{array}$ \\
& $\begin{array}{l}\text { byeongsinsaeki (병신새끼) } \\
\text { ssibalsaeki (씨발새끼) }\end{array}$ & $\begin{array}{l}\text { sialan, keparat, bajingan, brengsek, } \\
\text { bangsat }\end{array}$ \\
& doduknomsaeki (도둑놈 새끼) & keparat pencuri, pencuri, maling \\
& jotbapsaeki (좇밥 새끼) & pecundang, cecunguk lemah \\
& jotpiri (좇삐리) & tidak diterjemahkan \\
& ssibalnom (씨발놈) & bangsat \\
& gaejasik (개자식) & sialan \\
gaebyeongsin (개병신) & orang cacat \\
Michin saeki (미친 새끼) & keparat sinting, dasar bodoh \\
& saken saeki (삭은 새끼) & bedebah busuk \\
& napen nomdel (나쁜 놈들) & orang-orang gila \\
& jotbap gaten saeki (좇밥같은 새끼) & anak ceking culun \\
\hline
\end{tabular}

(Sumber data: data temuan penelitian)

Berdasarkan Tabel 7, berikut ini adalah penjelasan mengenai teknik penerjemahan yang digunakan untuk menerjemahkan ganghwa yokseol yang ditemukan dalam data korpus. Paparannya sebagai berikut.

Pertama, transposisi (transposition). Layaknya penerjemahan gibon yokseol, terdapat ganghwa yokseol yang diterjemahkan menggunakan teknik transposisi. Ganghwa yokseol dalam data korpus yang diterjemahkan menggunakan teknik ini adalah makian napen nomdel, sagen saeki, byeongsin saeki, michin saeki, jotbapgaten saeki, doduknom saeki, jotbap saeki, dan gaesaeki. Berikut ini adalah penjelasan mengenai struktur dari dua makian dalam data korpus yang diterjemahkan dengan teknik transposisi.
(2) napen

adjektiva

(menerangkan)

'orang-orang

nomina

(diterangkan)

(3) sagen

adjektiva

(menerangkan)

'bedebah

adjektiva

busuk'

(diterangkan)

adjektiva

(menerangkan)

Berdasarkan penjelasan di atas, makian napen nomdel dan sagen saeki mengalami perubahan dalam susunan kata. 
Tabel 7. Teknik Penerjemahan Ganghwa Yokseol

\begin{tabular}{|c|c|c|}
\hline Teknik Penerjemahan & Bahasa Sumber & Bahasa Sasaran \\
\hline \multirow[t]{8}{*}{ Transposisi (8 makian) } & napen nomdel (나쁜 놈들) & orang-orang gila \\
\hline & sagen saeki (삭은 새끼) & bedebah busuk \\
\hline & byeongsin saeki (병신 새끼) & anak tolol \\
\hline & michin saeki (미친 새끼) & keparat sinting \\
\hline & jotbapgaten saeki (좇밥같은 새끼) & anak ceking culun \\
\hline & doduknom saeki (도둑놈 새끼) & keparat pencuri \\
\hline & jotbap saeki (좇밥새끼) & cecunguk lemah \\
\hline & gaesaeki (개새끼) & bajingan sialan \\
\hline \multirow[t]{7}{*}{ Ekuivalensi (7 makian) } & gaesaeki (개새끼) & bajingan sialan \\
\hline & michin saeki (미친 새끼) & keparat sinting, dasar bodoh \\
\hline & byeongsin saeki (병신 새끼) & anak tolol, bangsat, keparat \\
\hline & jotbap saeki (좇밥 새끼) & pecundang, cecunguk lemah \\
\hline & sagen saeki (삭은 새끼) & bedebah busuk \\
\hline & napen nomdel (나쁜 놈들) & orang-orang gila \\
\hline & jotbapgaten saeki (좇밥같은 새끼) & anak ceking culun \\
\hline \multirow[t]{2}{*}{ Adaptasi (2 makian) } & jotbap saeki (좇밥 새끼) & pecundang, cecunguk lemah \\
\hline & jotbapgaten saeki (좇밥같은 새끼) & anak ceking culun \\
\hline \multirow[t]{9}{*}{ Penghapusan (9 makian) } & gaesaeki (개새끼) & $\begin{array}{l}\text { cecunguk, keparat, sialan, bedebah, } \\
\text { bangsat }\end{array}$ \\
\hline & doduknom saeki (도둑놈 새끼) & pencuri, maling \\
\hline & ssibalnom (씨발놈) & Bangsat \\
\hline & byeongsin saeki (병신 새끼) & bangsat, keparat \\
\hline & ssibal saeki (씨발 새끼) & $\begin{array}{l}\text { sialan, keparat, bajingan, brengsek, } \\
\text { bangsat }\end{array}$ \\
\hline & jotbap saeki (좇밥 새끼) & Pecundang \\
\hline & gaejasik (개자식) & Sialan \\
\hline & gaebyeongsin (개병신) & orang cacat \\
\hline & jotbapgaten saeki (좇밥같은새끼) & anak ceking culun \\
\hline Penambahan (1 makian) & gaebyeongsin (개병신 ) & orang cacat \\
\hline $\begin{array}{l}\text { Tidak diterjemahkan } \\
1 \text { makian) }\end{array}$ & jotpiri (좇삐리) & - \\
\hline
\end{tabular}

(Sumber data: data temuan penelitian)

Hal ini disebabkan karena frasa nomina dalam bahasa Indonesia berstruktur diterangkan - menerangkan (DM), sedangkan frasa nomina dalam bahasa Korea berstruktur menerangkan diterangkan (MD) (Dewi dan Wijaya, 2020:48). Pada contoh (2) dan (3), makian napen nomdel dan sagen saeki yang berstruktur MD diterjemahkan menjadi 'orang-orang gila' dan 'bedebah busuk' yang berstruktur DM. Hal ini menunjukkan bahwa kedua makian ini diterjemahkan dengan teknik transposisi.

Di samping kedua makian tersebut, makian byeongsin saeki juga diterjemahkan dengan teknik transposisi. Sedikit berbeda dengan penerjemahan pada contoh (2), terjemahan dari makian byeongsin saeki tidak hanya susunannya yang berubah, tetapi kelas katanya juga berubah. Berdasarkan KBBS, kata byeongsin (병신) merupakan nomina dan memiliki makna 1) 
신체의 어느 부분이 온전하지 못한 기형이거나 그 기능을 잃어버린 상태 yang berarti situasi ketika suatu bagian organ tubuh tidak ada atau kehilangan fungsinya; 2) 모자라는 행동을 하는 사람을 낮잡아 이르는 말 yang berarti kata yang digunakan untuk merendahkan orang yang bersikap buruk. Dalam bahasa Indonesia, nomina yang paling mendekati maknanya adalah 'cacat', namun situasinya kurang sesuai untuk menggunakan nomina tersebut. Perhatikan dialog yang menggunakan makian byeongsin saeki berikut.

(4) 으휴 또식이 저 병신 새끼. 더 처맞아야 돼.

[ehyu ttosigi jeo byeongsin saeki. Do chomajaya dwe.]

"Dasar Tosik- Anak tolol itu. Harus digebukin lagi."

Berdasarkan dialog tersebut, penutur menggunakan makian byeongsin saeki untuk memaki salah satu karakter bernama Tosik. Penutur bukan memaki Tosik karena ia punya kekurangan fisik, namun karena Tosik menolak untuk memberi alkohol pesanan penutur saat penutur berkunjung ke restoran milik ayah Tosik. Apabila nomina tersebut ditempelkan dengan padanan yang digunakan sebagai terjemahan dari saeki, yakni 'anak', penggunaan frasa 'anak cacat' kurang tepat. Oleh karena itu, penerjemah

menggunakan padanan 'tolol' dibandingkan dengan padanan 'cacat.' Hal yang sama juga terjadi pada contoh 3 , tidak hanya susunan kata tetapi kelas kata pada hasil terjemahannya juga berubah.

Kedua, ekuivalensi (equivalence). Selain teknik transposisi, ganghwa yokseol yang ditemukan dalam data korpus juga diterjemahkan dengan teknik ekuivalensi. Makian-makian yang diterjemahkan dengan teknik ini ialah gaesaki, michin saeki, byeongsin saeki jotbap saeki, sagen saeki, dan napen nomdel. Pada penerjemahan makian michin saeki, makian ini tidak hanya diterjemahkan dengan teknik transposisi tetapi juga menggunakan teknik ekuivalensi. Apabila dilihat pada Tabel 6, makian michin saeki memiliki dua terjemahan yakni 'keparat sinting' dan 'dasar bodoh.' Di antara kedua terjemahan ini, makna yang paling mendekati padanannya dengan makian michin saeki adalah 'keparat sinting' karena michida (미치다) berarti 'gila' dalam bahasa Indonesia. Sementara itu, ungkapan saeki yang mengikutinya diterjemahkan dengan salah satu padanan yang digunakan untuk menerjemahkan makian saeki dengan bentuk dasar. Berbeda dengan terjemahan tersebut, makna dari terjemahan 'dasar bodoh' tidak sepadan dengan michin saeki. Namun, apabila memperhatikan bagaimana situasi penggunaan makian ini, maka dapat diketahui mengapa penerjemah memilih padanan tersebut. Perhatikan dialog berikut yang mengandung ungkapan michin saeki dan diterjemahkan sebagai 'dasar bodoh.'

Penutur 1: 
저 건물 옥상으로, 그, 도둑놈하고. 방금-

그 분도 같이 모셔와.

[jeo geonmul oksangeuro, ge, doduknomhago. Bangem - ge bundo gachi mosyeowa]

"Ke atap gedung itu, bawa si pencuri, bersama dengan dua orang barusan."

Penutur 2:

어떤 식으로...?

[eoton sigero...?]

"Gimana caranya...?"

Penutur 3:

이- 미친 새끼가!

[i-michin saekiga!]

"Dasar bodoh...!"

Dialog pada contoh (5) tersebut merupakan salah satu dialog yang ada dalam webtoon Yakhan Yeongung. Dialog ini melibatkan tiga karakter yakni penutur 1 dan bawahannya, penutur 2 dan penutur 3 . Pada dialog tersebut, penutur 3 memaki penutur 2 karena ia merasa rekannya menanyakan hal yang tidak perlu setelah diperintah untuk melakukan sesuatu oleh penutur 1. Hal ini membuat penutur 3 berpikir bahwa penutur 2 melakukan hal yang bodoh, sehingga padanan 'dasar bodoh' digunakan untuk menerjemahkan makian dalam dialog ini.

Selain michin saeki, makian yang juga diterjemahkan dengan teknik ekuivalensi adalah makian gaesaeki. Pada Tabel 6, dapat dilihat bahwa salah satu terjemahan dari gaesaeki adalah 'bajingan sialan.' Meskipun kata gae (개) berarti 'anjing' dan merupakan makian dalam bahasa Indonesia, penerjemah tidak menggunakan padanan tersebut dan memilih padanan 'bajingan.' Karena apabila menggunakan padanan 'anjing', ungkapan 'anjing sialan' kurang sesuai sebagai makian dalam bahasa Indonesia. Umumnya, ungkapan tersebut digunakan apabila seseorang benar-benar memaki seekor anjing dan bukan seseorang. Sementara, padanan 'anjing' merupakan makian yang lazim digunakan dalam bahasa Indonesia.

Ketiga, adaptasi (adaptation). Teknik penerjemahan adaptasi tidak hanya digunakan untuk menerjemahkan gibon yokseol, tetapi juga ganghwa yokseol dalam data korpus yang telah ditinjau. Ganghwa yokseol yang diterjemahkan dengan teknik ini ialah jotbap saeki dan jotbapgaten saeki. Pada penerjemahan makian jotbap saeki, salah satu terjemahannya adalah 'cecunguk lemah'. Mengikuti padanan untuk gibon yokseol yang ada pada Tabel 4, kata 'cecunguk' merujuk pada saeki sementara jotbap diterjemahkan menjadi 'lemah'. Sebelumnya, telah dipaparkan bahwa makian jotbap tidak memiliki padanan yang sesuai dalam bahasa Indonesia sehingga diterjemahkan dengan teknik adaptasi. Hasil terjemahan dari teknik tersebut adalah 'pecundang', namun padanan tersebut kurang sesuai untuk dipakai sebagai terjemahan ungkapan jotbap saeki. Hal ini disebabkan padanan 'cecunguk' telah digunakan untuk mengindikasikan mitra penutur, sedangkan 'pecundang' juga memiliki fungsi yang sama. Oleh karena itu, 
penerjemah menggunakan padanan 'lemah' yang maknanya mendekati sifat yang dimiliki 'pecundang' sebagai terjemahan dari byeongsin. Sementara itu, makian jotbapgaten saeki memiliki terjemahan yang berbeda dengan makian sebelumnya yaitu 'anak ceking culun.' Pada penerjemahan ini, kata 'anak' merujuk pada makian saeki dan 'ceking culun' merujuk pada jotbapgaten. Meskipun terjemahan dari makian ini tidak menggunakan padanan 'lemah', namun tujuannya tetap sama yakni untuk merendahkan mitra penutur.

Keempat, penghapusan (deletion). Selain teknik-teknik yang telah dijelaskan di atas, ganghwa yokseol dalam webtoon Yakhan Yeongung juga diterjemahkan dengan teknik penerjemahan penghapusan. Vinay dan Dalbernet mengemukakan bahwa penghapusan (deletion) merupakan suatu teknik penerjemahan yang menghilangkan satu atau beberapa kata, frasa, klausa atau kalimat yang tidak diperlukan dalam sebuah teks (Dewi dan Wijaya, 2020:93). Dalam data korpus yang telah ditinjau, ganghwa yokseol yang diterjemahkan menggunakan teknik ini ialah gaesaeki, byeongsin saeki, ssibalsaeki, doduknom saeki, jotbap saeki, ssibalnom, gaejasik, gaebyeongsin dan jotbapgaten saeki. Berdasarkan Tabel 6, dapat dilihat bahwa sebagian besar makian yang awalnya merupakan sebuah frasa berubah menjadi sebuah kata. Misalnya, makian ssibalnom yang terdiri atas dua kata makian diterjemahkan sebagai 'bangsat' meskipun keduanya memiliki padanan tersendiri ketika diterjemahkan masing-masing.
Sementara itu, penerjemah tidak menerjemahkan seluruh ungkapan yang ada dalam makian gaesaeki dan doduknom saeki. Makian gaesaeki terdiri atas kata gae (개) yang berarti 'anjing' dan makian saeki, namun pada terjemahan ungkapan tersebut tidak ditemukan kata-kata 'anjing.' Hal ini membuktikan bahwa penerjemah tidak menerjemahkan kata gae ketika menerjemahkan makian gaesaeki dan hanya menerjemahkan kata saeki. Di sisi lain, makian doduknom saeki terdiri atas tiga kata yang berbeda yakni doduk (도둑) yang berarti 'pencuri', serta nom dan saeki yang merupakan makian. Namun, berdasarkan terjemahan yang dicantumkan dalam Tabel 6, doduknom saeki diterjemahkan sebagai 'keparat pencuri', 'pencuri' dan 'maling.' Hal ini menunjukkan bahwa penerjemah menerjemahkan kata doduk dan salah satu makian atau hanya menerjemahkan kata doduk saja.

Kelima, penambahan (addition). Di samping teknik-teknik yang telah dijelaskan, teknik penerjemahan penambahan juga digunakan untuk menerjemahkan makian yang ada dalam data korpus. Menurut Vinay dan Dalbernet, penambahan atau addition adalah teknik yang menambahkan satu atau beberapa kata, frasa, klausa atau kalimat untuk memperjelas konteks terjemahan agar tidak terlihat janggal (dalam Dewi dan Wijaya, 2020:92). Berdasarkan data yang telah ditinjau, makian yang menggunakan teknik ini untuk diterjemahkan adalah ungkapan gaebyeongsin.

Pada bagian sebelumnya, makian gaebyeongsin juga termasuk ke dalam 
makian yang diterjemahkan dengan teknik penghapusan. Karena sebelum diterjemahkan dengan teknik penambahan, makian ini juga diterjemahkan dengan teknik penghapusan. Dalam makian ini, kata gae dalam gaebyeongsin tidak diterjemahkan. Hal ini dibuktikan dengan tidak adanya kata 'anjing' yang merupakan makna dari gae pada terjemahan ungkapan tersebut. Namun, kata 'orang' diselipkan sebelum kata 'cacat' yang merupakan padanan dari byeongsin. Hal ini merupakan bukti dari adanya teknik penerjemahan penambahan. Apabila gaebyeongsin hanya diterjemahkan menjadi 'cacat', maka tuturan ini akan terdengar janggal untuk digunakan sebagai sebuah makian. Oleh karena itu, penerjemah menambahkan kata 'orang' agar tidak terdengar janggal dan jelas menunjukkan bahwa makian tersebut ditujukan untuk merujuk seseorang.

Selain diterjemahkan menggunakan teknik-teknik yang telah dipaparkan di atas, terdapat pula ganghwa yokseol yang tidak diterjemahkan. Di antara seluruh ganghwa yokseol yang muncul dalam data yang diteliti, hanya ada satu makian yang tidak ditemukan padanannya yakni jotpiri. Dalam menerjemahkan makian ini, penerjemah tidak menggantinya dengan padanan apa pun dan menghilangkan makna makian tersebut.

\section{KESIMPULAN}

Kata makian dalam bahasa Korea terbagi ke dalam 2 kelompok besar, yakni gibon yokseol dan ganghwa yeokseol. Sebaliknya, kata makian dalam bahasa
Indonesia tidak dibagi lagi menjadi beberapa kelompok besar. Namun, makian dalam bahasa Korea dan makian dalam bahasa Indonesia sama-sama memiliki referensi yang menjadi dasar dari kata makian tersebut. Dari data tersebut, makian dalam bahasa Korea yang ada di dalam webtoon Yakhan Yeongung dapat diterjemahkan ke dalam bahasa Indonesia. Satu makian dalam konteks tertentu dapat diterjemahkan dengan teknik yang berbeda.

Berdasarkan teknik penerjemahan Vinay dan Dalbernet (1995), teknik yang digunakan untuk menerjemahkan gibon yokseol dan ganghwa yokseol berbeda. Pada penerjemahan gibon yokseol, teknik penerjemahan yang digunakan adalah terjemahan harfiah, transposisi, ekuivalensi dan adaptasi. Teknik penerjemahan yang paling lazim digunakan adalah teknik ekuivalensi. Sementara itu, ganghwa yokseol yang muncul diterjemahkan dengan teknik penerjemahan transposisi, ekuivalensi, adaptasi, penghapusan dan penambahan. Teknik yang paling sering digunakan untuk menerjemahkan makian jenis ini adalah teknik penghapusan. Dalam penerjemahan makian-makian tersebut, teknik yang digunakan tidak hanya satu tetapi bisa juga menggabungkan satu teknik dengan teknik lainnya.

Lebih lanjut, berdasarkan kajian pustaka, ditemukan setidaknya tiga perbedaan antara makian dalam bahasa Korea dan bahasa Indonesia dilihat dari bentuk bahasanya. Dalam penelitian ini, perbedaan tersebut tidak dianalisis secara mendalam karena bukan tujuan dari 
penelitian ini. Ini membuka peluang untuk penelitian selanjutnya mengenai analisis perbandingan makian dalam bahasa Korea dan Indonesia.

\section{DAFTAR REFERENSI}

Baek, Y.M. (2013). An analysis of trend of verbal abusive language of university students. Korean Jurnal of Youth Studies 20(7), 1-21.

Chang, K.H. (2010). The nature and type of Korean abuses. Textlinguistics, 29(0), 401-427.

Crystal, D. (2004). The penguin encyclopedia. Penguin Books.

Dewi, H. D. \& Wijaya, A. (2020). Dasardasar penerjemahan umum. Manggu Makmur Tanjung Lestari.

Hatim, B. \& Munday, J. (2004). Translation: An advanced resource book. Routledge.

Hoed, B. H. (2006). Penerjemahan dan kebudayaan. Pustaka Jaya.

Kim, S.Y. (2002). A study on the characteristics of abuse in Korean speech and discourse analysis, 4(0), 271-290.

Ljung, M. (2011). Swearing: A crosscultural linguistic study. http://doi.org/10.1057/9780230292376

Nirwana, A. S. A. \& Usmi. (2019). Penerjemahan kata bermuatan budaya dalam novel Laskar Pelangi dan Bellitung Seomui. Proceeding of the International University Symposium on Humanities and Arts (INUSHARTS)
4.0, hal. 540-555. Universitas Indonesia.

Ni Made, P. R. (2012). "Analisis penerjemahan idiom bahasa Indonesia dalam novel Laskar Pelangi ke dalam bahasa Korea." Tidak diterbitkan. Fakultas Ilmu Pengetahuan Budaya Universitas Indonesia.

Putri, D. M. (2018). "Pengaruh media sosial LINE Webtoon terhadap minat membaca komik pada mahasiswa Universitas Riau." JOM FISIP, Vol. 5 No. 1. Fakultas Ilmu Sosial dan Ilmu Politik Universitas Riau.

Pyojun gug-eo daesajeon. Diakses pada 3 April $2020 \quad$ melalui http://stdict.korean.go.kr

Rahman, S. (2017). "Swearing: A crosscultural study in Asian and European languages." Radboud University Nijmegen.

Rosidin, O. (2010). "Kajian bentuk, kategori, dan sumber makian, serta alasan penggunaan makian oleh mahasiswa." Tidak diterbitkan. Fakultas Ilmu Pengetahuan Budaya Universitas Indonesia.

SeoPass \& Kim, J. (2018). Yakhan yeongung. Naver Webtoon.

SeoPass \& Kim, J. (2019). Weak hero. Diterjemahkan oleh LINE Webtoon Indonesia. LINE Indonesia

Son, J.H., et al. (2012). A qualitative study for the youth in the use of profanity. Forum for Youth Culture VOL.33, 146172. 
Sugiyono. (2013). Metode penelitian kuantitatif, kualitatif dan $R \& D$ (Ed. ke19). Alfabeta.

Vinay, J. \& Dalbernet, J. (1995). Comparative stylistics of French and English. John Benjamins Publishing Company.

Vingerhoets, A., et al. (2013). Swearing: A biopsychosocial perspective. Psychological Topics 22, hal.287-304.

Wijana, I.D.P \& Rohmadi, M. (2012). Sosiolingustik: Kajian teori dan analisis. Pustaka Pelajar.
Yang, H.R. (2019). "A study on the formation of the language culture of Korean adolescents: Focus on swearing, vulgar words, adolescents' slang and buzzwords." The Graduate school of Education, Yonsei University.

Yi, J. S., et al. (2017). Service design for improving adolescents' cyber language habit. Lecture Notes in Computer Science Design, User Experience, and Usability: Understanding Users and Contexts, 403-414.

https://doi.org/10.1007/978-3-31958640-3_29 